\title{
TOPICS 非線形光学材料としての超薄膜
}

非線形光学素子は入射光の波長を $1 / 2$ または $1 / 3$ に 変換したり，振動数 $\nu_{1}$ の光から $\nu_{2}$ と $\nu_{3}$ の二つの光 が発生する光パラメトリック発振なぞの機能を有す る.たとえば大出力赤外レーザ光を可視光または紫外 光に変えることや, 波長の異なった数種の光を入射し て光混合することが可能となる.これらは光通信関係 だけでなく, 光情報処理, 集積光学, 化学種の励起光 用素子など，幅広く応用されると思われる。

現在は主に $\mathrm{LiNbO}_{3}$ や $\mathrm{KDP}$ といった無機材料が 非線形光学素子として用いられているが，最近，無機 物の数十倍もの大きな変換係数を有する有機物や高分 子が合成されて特り，来るべき光の時代に非常に期待 されている。

光が物質を通過する時, 分極を誘起する. 光の電場 を $E$ とすると誘起され分極 $P$ は次式で示される1).

$$
P=\chi^{(1)} E+\chi^{(2)} E E+\chi^{(3)} E E E+
$$

ここで $\chi^{(n)}$ は感受率であり $\chi^{(2)}$ 以上を非線形感受 率という。一般に $\chi^{(2)}, \chi^{(3)}$ は小さいので光強度が 弱い場合は第 1 項が顕著に観察される．強いレーザ光 を照射すると，高次項は無視できなくなるが，中心対 称性の結晶ではその反像操作により偶数次の係数は 0 となる。非中心対称性結晶だけが有限の $\chi^{(n)}$ を有す る. 今, 入射光の時間変化を $E=E_{0} \cos \omega t$ とすると 第 2 項 $P_{2}$ は次式のよらになる.

$$
\begin{aligned}
P_{2} & =\chi^{(2)} E^{2} \\
& =(1 / 2) \chi^{(2)} E_{0}{ }^{2}(1+\cos 2 \omega t)
\end{aligned}
$$

すなわち $P_{2}$ は二つの成分，直流的なバイアス分極と 2 倍の周波数成分による分極とからなっている。これ により透過光は 2 倍の周波数をもった光となる.これ を2次高調波 (SHG) という， 禹(3) が大きい場合は 3 倍の周波数成分を有する透過光が存在する。京た(1) 式から数種の異なった周波数の光を入射した時に和

（差）周波が発生することも明らかである. 非中心対 称性結晶にレーザ光を照射してもかならずしも SHG が観測されるとは限らない，入射した光は結晶中のそ れぞれの部位で 2 次高調波を発生させるが，それぞれ の位相が一致しないと，干渉して消隇する，それゆ党 位相整合が大変重要である。

大きな SHG を示す条件としては（1）分子鎖およ び結晶が非中心対称をもつ2，（2）長い $\pi$ 電子共 役2)，(3）電子を押し出す傾向の原子団々引き达む傾 向の原子団を共役鎖を介して導入する，(4) 高結晶 性，（5）強度が大きく光破壊されない2，（6）屈折 率の異方性が大さい，(7) 入射光拈よびその SHG 周波数域で光の吸収がないことなどがあげられるが， さらに実用的には表面が平滑で大きな結晶が作れるこ となどが加えられる。

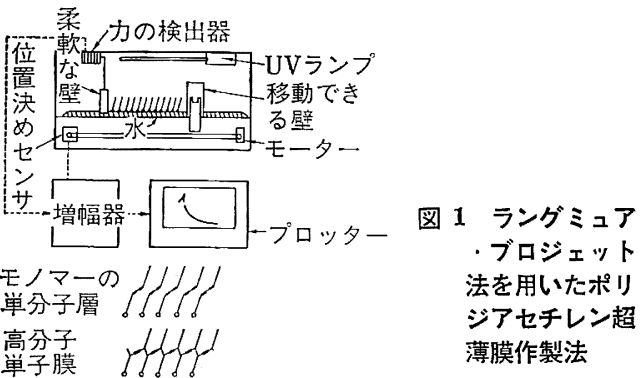

また引加電界に比例して屈折率が変化し, 光を変調 させる効果を示す線形電気光学効果 (ポッケルス効果)

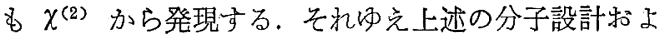
び高次構造設計の概念がそのまま適用可能である.し か乙, 線形電気光学効果は電子と格子振動の励起によ って発現するのに対して, SHG の場合, 電子励起に 起因する。

大きな $\chi^{(2)}$ をる有機物として 2-メチル-4-ニト ロアニリン (MNA) が合成されている2).これは SHG の大きさの尺度であるミラー指数 $\delta$, ポッケルス効果 の尺度 $f$ の值が $\mathrm{LiNbO}_{3}$ の約 20 倍も大きい"1) 乙 かし有機結晶は, 強いレーザ光により光破壊が起こ り，また化学的安定性に欠ける．高分子化してこれら の欠点の改良がなされている。

ポリジアセチレンは側鎖に MNA やメタニトロア ニリンなどを導入することが可能である，重合収縮が 少ないので光学的に均一な単結晶を形成しやすい，乙 かも主鎖中の $\pi$ 電子が光により分極しやすいので盛ん に研究されている，またこの物質は大きな $\chi^{(3)}$ を有 している，図1に森リジアセテレンのラングミュア・ ブロジェット法による超薄膜作製法を示す3). モノマ 一の状態で水面上に単分子膜を形成し，UV 照射で重 合した後，電極上にすくい取る方法である，この方法 により，単分子層の厚さで膜厚を制御できる。そのた めに光学的ロスのほとんどない膜となる．光導波素 子, 光増幅素子として光集積回路用材料や, 紫外線, X線，電子ビームリソグラフの技術により光学デバイ スの可能性も検討されている.

\section{文献}

1） A. Yariv 著, 多田, 神谷訳, 光エレクトロニク スの基礎，丸善 (1974) p. 187

2) A. F. Garito, K. D. Singer: Laser Focus, No. 2, 59 (1982)

3) S. K. Tripathy, G. M. Carter, et al. : A.C.S. Polym. Prept., 143 (1982)

宮田清蔵（東京農工大学工学部 - 助教授, 専門=高分 子物性） 